\title{
WHY GENERAL JURISPRUDENCE IS INTERESTING
}

\author{
JULIE DICKSON \\ University of Oxford \\ Faculty of Law \\ julie.dickson@law.ox.ac.uk
}

SUMMARY: In a recent article entitled, "Is General Jurisprudence Interesting?", David Enoch answers his own question resoundingly in the negative. This article critically examines the character of Enoch's claim, the presuppositions it rests on, and the way in which he seeks to establish it. Having argued that many of Enoch's views in this regard hinge on a narrow and idiosyncratic understanding of the questions that general jurisprudence addresses, and of the relations between those questions and many other inquiries concerning the character of law, the article concludes by offering its author's own vision of what makes general jurisprudence engaging, intriguing, and... well... interesting.

KEY WORDS: legal philosophy, methodology, indirectly evaluative legal philosophy

RESUMEN: En un artículo reciente titulado "Is General Jurisprudence Interesting?", David Enoch responde su propia pregunta de forma sonoramente negativa. Este artículo examina críticamente la naturaleza de la afirmación de Enoch, las presuposiciones sobre las que descansa y la manera en la que intenta mostrar que tal es el caso. Habiendo argüido que muchas de las visiones al respecto dependen de un entendimiento pobre e idiosincrásico de las cuestiones de las que se ocupa la teoría general del derecho, así como de las relaciones entre esas cuestiones y muchas otras investigaciones acerca de la naturaleza del derecho, el artículo concluye ofreciendo la propia versión de la autora acerca de aquello que hace de la teoría general del derecho algo intrigante, cautivador y... también... interesante.

PALABRAS CLAVE: filosofía del derecho, metodología, filosofía del derecho indirectamente evaluativa

\section{Introduction}

When Pau Luque, editor of this special issue of Crítica devoted to legal philosophy, first approached me with the idea of writing a contribution for it, he strongly piqued my interest by mentioning his intention to explore whether general jurisprudence is philosophically interesting, and to do so using as a springboard into this topic, David Enoch's recent claim that it is not. ${ }^{\text {l }}$ Pau very kindly offered me two options for my article: to discuss and critically engage with Enoch's

${ }^{1}$ The Enoch-related parts of the following discussion focus on his views as expressed in David Enoch, "Is General Jurisprudence Interesting?", forthcoming in D. Plunkett, S. Shapiro, K. Toh (eds.), Ethical Norms, Legal Norms: New Essays on Metaethics and Jurisprudence (Oxford University Press, New York), and a version of which is available at SSRN: 
views on this topic, or, alternatively, to discuss more generally my own views on the character, aims, and interestingness of general jurisprudence. Embracing those qualities of vacillation and contrariness for which academics are often known and justly lampooned, ${ }^{2}$ I decided in the end to do neither in the sense of doing (a bit of) both: this article hence critically examines and contests some of Enoch's views, while offering and exploring aspects of my own views on the character, aims, and interestingness of legal philosophy.

The discussion is structured as follows. In section 2, I begin by considering Enoch's case for answering the question "Is General Jurisprudence Interesting?" (Enoch 2015) in the negative. I then offer a critical analysis of the way in which he approaches this question and argues in favour of his conclusions. In section $3 \mathrm{I}$ focus on, and seek to refute, Enoch's view that the sorts of questions often addressed by legal philosophers concerning the normativity of law are (relatively) lacking in philosophical interest. In so doing, I make a positive case for the view that questions concerning the normativity of law have generated particularly interesting conundrums, which themselves have given rise to further engaging puzzles concerning how various dualities inherent in law can be adequately understood.

Section 4 argues in favour of understanding jurisprudential inquiry as having a broad remit, and seeks to emphasize the (overlooked by Enoch) deep and important relations of complementarity and continuity which exist between various sorts of questions addressed by legal philosophers. Section 5 continues and extends the discussion by presenting my own vision of what we should be doing, and how we should be doing it, when we engage in the philosophy of law.

\section{On Enoch's Approach to Establishing that General} Jurisprudence Is Not Philosophically Interesting

In, "Is General Jurisprudence Interesting?", David Enoch argues that it is not. Or rather, to render his thesis in terms of his self-proclaimed aims, he argues that general jurisprudence is not that philosophically interesting as compared with meta-ethics: more specifically, that questions concerning the character and status of the normativity of law, and the validity of legal norms, are "nowhere nearly as interesting"

$<$ https://papers.ssrn.com/sol3/papers.cfm?abstract_id=2601537 $>$. As the work has not yet been published, all page references are given according to the SSRN version, hereinafter referred to as "Enoch 2015".

${ }^{2}$ Academic satire (rightly) abounds. Favourites of mine include Lurie 1984, DeLillo 1985 and Russo 1997. 
(Enoch 2015, p. 2) as analogous questions concerning the character and status of the normativity of morality, and the validity and reasongivingness of moral norms (Enoch 2015 passim).

Enoch canvasses several reasons why, in his view, the normativity of morality generates significantly more interesting philosophical questions than the normativity of law. These include:

(1) moral normativity is "full-blooded" in character, hence to explain moral normativity, philosophers must address issues such as how, if at all, moral norms can provide genuine reasons for action, be objective, motivate conduct (2015, sec. 3$)$, whereas legal normativity is highly likely to be "formal normativity" (2015, pp. 7-8 and sec. 4) which - and an adequate explanatory account of which — "can be had for relatively cheap" (2015, p. 7) as it consists merely of criteria of correctness relative to a set of rules or norms devised by human beings and their social practices, such as whether the bishop may or may not be moved diagonally according to the rules of chess, or whether or not one ought to wear white after the United States' Labor Day holiday according to the norms of fashion, and hence does not raise interesting questions concerning genuine reasons for action, objectivity, or motivating and/or justifying conduct; (2015, sec. 4)

(2) in the case of moral normativity, complex and intensely contested philosophical debates address genuine puzzles regarding whether moral facts and properties are response-dependent or response-independent, whereas in the case of legal norms, it is obvious and uncontroversial that the validity of legal norms is significantly responsedependent, so interesting philosophical debate on this matter is hence much thinner on the ground; $(2015$, sec. 6)

(3) that meta-ethics makes a difference to, and hence has interesting implications for, first order normative ethics, whereas jurisprudence does not appear to have analogous first-order implications for the creation, development, and application of law, for example in matters regarding how judges should decide cases or in questions concerning the proper design and relative power of various legal institutions such as courts and legislatures. (2015, sec. 7)

Enoch devotes most of his article to discussing reason (1) for the relative uninterestingness of general jurisprudence, and I follow suit, tackling this issue in some depth in sections 3 and 4 below. For the 
remainder of the present section, however, I seek to highlight some preliminary problems with the way in which Enoch approaches his discussion, problems which turn out to have important implications for the strength and cogency of the arguments he makes and the conclusions he seeks to establish.

The problems begin in the introductory section of "Is General Jurisprudence Interesting?", when Enoch states that he does not think it necessary to offer a definition of "general jurisprudence" (2015, p. 3). In justifying this view, he makes the somewhat underexplained claim that: "Here as often elsewhere too, we know what we are talking about, and definitions are of little philosophical interest" (2015, p. 3). His point regarding definitions specifically may well be sound, and marks a point of firm agreement between Enoch and one leading proponent of general jurisprudence, namely H.L.A. Hart (Hart 2012, chap. 1; Hart 1983, Essay 1). However, Enoch's view that he need not linger over providing his readers with an adequately precise, determinate, and accurate characterisation or account of the target he has in mind is problematic in terms of the arguments he proceeds to offer. ${ }^{3}$ For, far from us all knowing and agreeing upon what we are talking about, Enoch's narrow and somewhat peculiar view of what constitutes general jurisprudence, which emerges in the remainder of his article, seems, at least to me, to distort and misrepresent both the questions asked and the wide range of answers to those questions given by those working in this field.

For example, at several points in "Is General Jurisprudence Interesting?", Enoch claims that "obviously, the wars over legal posi-

${ }^{3}$ It should be noted that, in footnote 4 of "Is General Jurisprudence Interesting?", Enoch seemingly attempts to offer a kind of characterisation of general jurisprudence, when he says the following: "If you really feel the need for a more definition-like characterization, I'm happy to take on board the one that Plunkett and Shapiro (forthcoming) put forward. Roughly, they characterize general jurisprudence as general meta-legal inquiry: it is the area of philosophy that aims to explain how general legal thought and talk - and the part of reality (whatever it is) that this thought and talk is about (e.g., legal facts, properties, relations, etc.) - fits in with the rest of reality" (Enoch 2015, n. 4). However, my view is that, as it is rendered in Enoch's footnote 4, this characterisation is significantly vague and under-specified, and does not take us further forward in ascertaining exactly what, and whom, Enoch takes as his target. Moreover, in my view, Enoch fails to capture the fullness and nuance of the view of the domain and tasks of general jurisprudence actually espoused by Plunkett and Shapiro, which is also unfortunate and does not add clarity to the inquiry. Interested readers can pursue this further, and make up their own minds in this regard, by reading in full the latest work in progress version of the Shapiro and Plunkett paper that Enoch is referring to, see Shapiro and Plunkett 2017. 
tivism" (2015, p. 1) are a centrally important part of general jurisprudence. He refers to contemporary general jurisprudence as being engaged in "the metaphysical project of which the wars over positivism are a major part" (2015, p. 31), and avers that:

The controversy over legal positivism - how best to understand it, whether it's true, the distinction between different kinds thereof, and so on- is of course central to these discussions [of general jurisprudence], but does not exhaust them. $(2015 \text {, p. } 3)^{4}$

Does not exhaust them? In my view, it is a significant mistake to hold that what sounds from Enoch's characterisation of it to be a sort of perpetual intra-mural jurisprudential ping-pong regarding what constitutes one school of thought to which some legal philosophers are alleged to belong, does, or should, form any significant part of legal philosophers' endeavours in attempting to understand the nature of law.

I am far from alone in holding this view. Several important contemporary legal philosophers are highly sceptical of: (i) the usefulness of such jurisprudential labels in general, (ii) engaging in extended debates concerning what, and who, the labels properly refer to, and (iii) framing debates about the nature of law in terms of those positions which would allegedly be taken by those on one or other side of various dubious school-of-thought dividing lines. Neil MacCormick, for example, persistently criticised those who spend time and energy dividing the jurisprudential scene into "legal positivism" and "natural law", and who erroneously understand debates about the character of law in terms of who stands where in such a "two-way-divided universe of jurisprudence" (MacCormick 2007, p. 278), insisting that:

In truth, such dichotomies [between legal positivism and natural law] are rarely revealing of any important truth. (2007, p. 278)

It is better to reject the aforesaid dichotomy as based on a misleading account of the history of legal ideas than to trouble responding to the question: “Are you a positivist or a natural lawyer?" (2007, p. 279)

Joseph Raz, often characterised by others as a "legal positivist", and then sub-characterised as a "hard" or "exclusive" legal positivist, has also persistently disavowed the usefulness and applicability of the label, and does not believe that framing jurisprudential debates in terms of it will yield insightful results:

\footnotetext{
${ }^{4}$ See also pp. 6, 25, 29, and 31.
} 
The harm is done by proceeding to make the division between "legal positivists" and "natural lawyers", so defined, the basic division in legal philosophy. (Raz 2003, p. 2)

Perhaps it is time not to refute legal positivism, but to forget the label and consider the views of various writers within that tradition on their own terms. (Raz 2007, p. 35)

Other theorists, too, harbour doubts about the usefulness of the label "legal positivism", particularly in light of the many misunderstandings and over-extensions of it which feature in some jurisprudential literature. ${ }^{6}$ Moreover, in many instances where legal philosophers do in part frame their discussions in terms of who stands where, and where it is coherent and tenable to stand at all, as regards "legal positivism" and its various alleged sub-types (hard, soft, inclusive, exclusive, etc.), their primary focus is not on that label, but on enduring questions and puzzles about the nature of law, such as the existence, character and success conditions of law's claim to possess moral authority over its subjects, ${ }^{7}$ the relationship between law and morality as manifest in judges' duties in constitutional and other adjudication to act properly in terms of both the legal and the moral constraints upon them (Waluchow 2000, Raz 2004), and the social and institutional nature of law, and what consequences this has for the jurisprudential methodology we should adopt in theorising about it. ${ }^{8}$ In discussing these issues, legal philosophers wrestle with puzzles about the nature of law and its various relations with morality, and explore law's potential and actual value, function, and place amongst those other social and normative phenomena which shape our lives. ${ }^{9}$ To (mis)understand such debates as mere jurisprudential in-fighting about who is what kind of legal positivist, and whose version of legal positivism "wins" the alleged "wars over legal positivism" (Enoch 2015 , pp. 1 and 31 ) is to miss quite fundamentally both their object and their point.

Enoch's idiosyncratic and, ultimately, narrow view of contemporary general jurisprudence extends beyond his claims that the "wars over positivism" form a central component of such inquiry, and significantly influences his overall thesis that general jurisprudence

${ }^{5}$ For the defintions, Raz refers to Raz 2003, passim.

${ }^{6}$ See e.g. Gardner 2001.

${ }^{7}$ See e.g. Raz 1985, Green 1988, Waluchow 1994, Leiter 1998.

${ }^{8}$ See e.g. Green 2003, Dickson 2012.

${ }^{9}$ The connections between these various inquiries are discussed further in sections 3 and 4 below. 
holds little philosophical interest. He contends throughout "Is General Jurisprudence Interesting?" that another major concern of the eponymous pursuit is to ascertain the necessary and sufficient conditions of law's "formal normativity", a kind of normativity which, as was outlined above, is understood by Enoch to consist merely of criteria of correctness relative to a set of norms devised by human beings and their social practices and institutions, and which hence does not raise interesting questions concerning genuine reasons for action (Enoch 2015, secs. 3-5). Once again, though, Enoch's claims reveal him to hold an idiosyncratic and etiolated view of the province of general jurisprudence.

First, he over-states the extent to which inquiries concerning law's "formal normativity" need shoulder alone the responsibility for general jurisprudence's philosophical interest: "If what is supposed to render jurisprudence interesting is law's formal normativity [...]" (Enoch 2015, p. 21). Then, he defines inquiries regarding law's "formal normativity" in very restrictive terms, and appears to view them as confined to working out the necessary and sufficient conditions of legal validity in a hermetically sealed bubble of inquiry, divorced from important related questions concerning law's moral authority and legitimacy, and its ability to generate moral reasons for action and moral obligations to obey it (2015, secs. 3-5; especially at pp. 21-22 and 31). ${ }^{10}$ So far as I can see, however, it is only Enoch himself who believes that what is primarily supposed to make general jurisprudence interesting are the opportunities it presents to study law's formal normativity understood only as ascertaining the correctness conditions of legal validity, and nothing more than this. Can the breadth, depth and variety of the legal philosophical work of, just to pick some examples, Brian Leiter, Leslie Green, Amanda Perreau-Saussine, Wil Waluchow, Jules Coleman, Amalia Amaya, John Finnis, and Veronica Rodriguez-Blanco, really be understood in such narrow and attenuated terms?

Unfortunately, it is difficult to know the answer to this, because it is difficult to know exactly which legal philosophers, and which works in general legal philosophy, Enoch has in mind, owing to a second difficulty with the way he presents his case for general jurisprudence's lack of philosophical interest. Throughout "Is General Jurisprudence Interesting?", there is a significant lack of referencing of, and citing to, the actual work in general jurisprudence which Enoch finds so uninteresting. For instance, none of the theorists who I pick out

${ }^{10}$ See further the discussion in sections 3 and 4 of this article. 
above, and who have spent considerable portions of their professional lives engaging in general jurisprudence are referenced, or their work discussed, at all.

As a result of this aspect of Enoch's approach, we do not know who, or which works, are the target of his charges, and hence cannot evaluate with any degree of specificity the extent to which the charges might stick. The lack of discussion of, and references to, specific works in contemporary general jurisprudence also leaves out of consideration much important work on the normativity of the law, and on a wide variety of topics beyond the normativity of the law, work which, had it been examined, would at the very least give substantial food for thought regarding what is philosophically interesting about it. Enoch's lack of engagement with such works unfortunately robs the reader of a chance to assess how he views them, and the extent to which he would still regard the specific puzzles and questions they address, and the way they address them, as significantly lacking in philosophical interest. ${ }^{11}$

These two problems - Enoch's adoption of an idiosyncratically narrow view of what constitutes general jurisprudence, and a significant paucity of discussion and referencing of those works he takes as his target - are compounded by a third: a pervasive tendency to overstate his case, despite repeated assurances that he is not doing so.

Trouble starts early in this regard, with Enoch claiming in the opening paragraphs of his article:

A provocative way of putting my conclusion is that general jurisprudence is not that interesting. As things will develop, it will be clear that this is too strong and general way of making my point, but it's a good start. (Enoch 2015, p. 1)

If, by Enoch's own admission, this is an overstatement, and is a too strong and overly-general way of making his point, what makes it a good start? That a provocative claim is somehow better than an accurate one? More importantly, it is a start which ricochets down the rest of his article, to its detriment. Because despite repeatedly claiming that he wishes only to argue that general jurisprudence is relatively less interesting than meta-ethics - specifically, that general jurisprudence's alleged focus on law's formal normativity is less interesting than meta-ethics' focus on puzzles concerning the character of

${ }^{11}$ See further sections 3 and 4 below. 
"full-blooded normativity" - Enoch repeatedly reaches conclusions which range considerably, and, at times, intemperately, beyond this.

One example of this has already been noted above, when Enoch claims that "If what is supposed to render jurisprudence interesting is law's formal normativity [...]" (2015, p. 21), then jurisprudence lacks philosophical interest to the point where it is no more worthy of academic study than "meta-fashion, meta-etiquette, and metabaseball" (2015, p. 21). But this assumption of "what is supposed to render jurisprudence interesting" is Enoch's alone, and in allowing so much to turn on it as regards whether jurisprudence is any more worth studying than "meta-baseball", he appears to mislay more than somewhat his claimed open-mindedness that there may be a plethora of other ways in which general jurisprudence is interesting. ${ }^{12}$ As the article continues, Enoch's claim that jurisprudence's formal normativity is not any more interesting than fashion or etiquette's formal normativity, appears to pull him headlong to the conclusion that general jurisprudence as an academic discipline is perplexing and redundant:

There are no, as far as I know, international conferences devoted to meta-fashion. There are no scientific journals whose main order of business is to do meta-etiquette.

Jurisprudence, on this picture, may just be meta-fashion with larger research funds. (Enoch 2015, both quotes are at p. 21)

Such conclusions are repeated and extended as the article moves towards its close:

The point I want to note here, though, is that the most jurisprudence (of the kind I've been discussing) can hope for is to be as interesting as this study of etiquette. (Enoch 2015, p. 27)

And, indeed, even this significantly attenuated hope turns out to be in vain:

It seems unlikely to me that this hope will be realized - for the ways of etiquette seem to me to be much more intricate and complicated [...] than those of the law. (Enoch 2015, p. 27)

${ }^{12}$ Enoch makes the more open-minded claim in Enoch 2015, pp. 2-3. 
The article ends with Enoch counselling general jurisprudes to abandon their current sterile and uninteresting pursuits and turn to something else, a jurisprudence allegedly very differently in character, which is: "an important part of moral and political philosophy" (p. 31). But general jurisprudence, as is manifest in existing high quality work in contemporary legal philosophy, already and inevitably is an important part of moral and political philosophy, and understands itself to be so. Enoch's tendency to over-state the conclusions that his argument can establish appears to contribute to his misunderstandings regarding both that which he seeks to criticize, and that which he advocates as its replacement. ${ }^{13}$

These three features of the way that Enoch makes his case -adopting an idiosyncratically narrow view of what constitutes general jurisprudence, a lack of discussion and referencing of the work he takes as his target, and a tendency to yield to the siren song of provocative overstatement - unfortunately weaken his argument, and significantly distort his discussion, thus making it more difficult to gain an accurate picture of what he thinks general jurisprudence does currently, and what he thinks it ought to do in future. This, in turn, makes Enoch's views more difficult to engage with for those seeking precise common ground on which to do so. Despite this, however, the central issue which Enoch raises is thought-provoking and useful, at least in terms of prompting proper consideration of what is interesting about studying the normativity of law.

\section{Interesting Puzzles Concerning the Normativity of Law: Law as Social Fact and Moral Value}

As was outlined in section 2 above, central to Enoch's thesis in "Is General Jurisprudence Interesting?" is his view that the normativity of the law, being of a "formal" kind, does not engender interesting philosophical questions concerning its character. An explanation of such formal normativity, Enoch claims, "can be had for relatively cheap" (2015, p. 7), as it consists merely of criteria of correctness relative to a set of rules or norms devised by human beings and their social practices, such as whether the bishop may or may not be moved diagonally according to the rules of chess, or whether or not one ought to wear white after the US Labor Day holiday according to the norms of fashion (2015, secs. $3-5)$ :

\footnotetext{
${ }^{13}$ This point will be discussed further in sections 4 and 5 below.
} 
Set up a game - no one is allowed to step on the lines - and immediately some actions are correct (stepping between the lines) and some aren't (stepping on the lines). And this suffices for some normativesounding language ("No, you shouldn't step on the lines!", "Yeah, you're okay, you didn't step on any line.", and so on). (Enoch 2015, p. 7)

In characterising formal normativity in this way, Enoch gives the impression that all legal philosophers need do in explaining law's normativity is identify the criteria of correctness, relative to a set of humanly devised norms, of a norm being legally valid, then state what these criteria are, in generalized terms. ${ }^{14}$ So, for example, the explanation could run as follows:

in the practice of law in the England and Wales legal system, a norm is legally valid if it is contained in a statute which successfully passes a vote in the House of Commons and in the House of Lords (of the Westminster Parliament), and is given the Royal Assent. ${ }^{15}$ Abstracting from these particular criteria, and rendering the point in a generalized rather than jurisdictionspecific way, a norm is legally valid in a jurisdiction if it meets the relevant social fact-based criteria by which norms are rendered legally valid in that jurisdiction, and if those social factbased criteria are accepted and used to determine legal validity in that jurisdiction by the legal officials of that jurisdiction.

It will readily be identified that this is very much along the lines of a rules of recognition-based account of legal validity such as that offered by H.L.A. Hart. ${ }^{16}$ The problem, however, is that Enoch makes it sound as though offering an account of legal validity as above is swift and simple, and represents general jurisprudence's "job done" so far as explaining law's normativity goes. This is erroneous in two main ways.

First, it involves significantly overlooking the fact that the view now enjoyed in this regard is so clear and far-reaching because of the intellectual shoulders upon which we rest. Hart's account of

${ }^{14}$ I base this view on what Enoch says about formal normativity in "Is General Jurisprudence Interesting?", p. 7, and on what he says about legal validity at pp. 2425.

${ }^{15}$ This is simplified for the sake of explanation: statutory enactment being, of course, only one route to creating valid law in the England and Wales legal system.

${ }^{16}$ See Hart 2012, especially chaps. 5 and 6. 
the place of rules in understanding law, and his insightful and nonreductive (contra his jurisprudential predecessors) explanation of how secondary rules of recognition govern how law is made, changed, recognised, and administered, is a victim of its own success. Having long had the benefit of Hart's insights, contemporary legal philosophers often significantly discount the extent of the progress made, and the clarity in understanding gained, as a result of Hart's work on these matters.

Secondly, the "identify and then generalise the criteria of legal validity and that is job done" approach adopts a narrow and overly circumscribed view of what an explanation of the normativity of law ought to cover, and fails to recognise the connections between, for example, identifying and characterising criteria of legal validity, and any number of puzzling and fascinating further questions regarding the nature of law and the manner of its operation. For Enoch, that legal norms are man-made, social-institutional, and significantly constituted by and dependent upon human social practices, attitudes, behaviour, intentions, is presented as a reason why they are not interesting as compared with meta-ethical inquiries regarding moral norms. ${ }^{17}$ For many legal philosophers, however, these features are precisely why the normativity of law is so interesting and are exactly that which lights the way toward some fascinating puzzles concerning the normativity, authority, and reason-givingness of the law.

What do I mean by this? For present purposes, allow me to outline only a selection of the many intriguing puzzles which both past and contemporary legal philosophers have viewed as stemming from those features of legal norms mentioned above, and which they have explored in a way which, to my mind, reveals their philosophical significance and importance. Several leading legal philosophers follow Enoch in regarding what he refers to as full-blooded or moral normativity as the paradigm case of normativity. That is to say, they hold that a norm, " $X$ ought to $\phi$ " entails that $X$ has a - genuine, moral if we want to use that terminology - reason to $\phi$, a reason provided by the fact that there is —once again, genuine, moral — value in $\phi$-ing. ${ }^{18}$ For such theorists, it is precisely in light of this that the normativity of the law is so puzzling and in need of investigation and explanation: how can legal norms, which come into existence in virtue of particular contingent human social-institutional practices and actions, purport

${ }^{17}$ See Enoch 2015, sections 3-6 inclusive.

${ }^{18}$ See e.g. Raz 2009, chaps. 7 and 8; Finnis 2001, passim, but see especially chaps. I, IX.2, XII; Gardner 2007, passim. 
to generate, and under some circumstances actually generate, genuine reasons for action which are a hallmark of normativity? To put the matter more concretely, as I sometimes do in seeking to interest my students in questions regarding the claimed moral authority and obligatoriness of the law: how could the facts and social facts of at least $50 \%$ plus 1 Members of Parliament walking through the "Aye" rather than the "No" lobby in what we call the House of Commons in that grandiose building beside Westminster bridge on the river Thames in London ever "change morality", change what reasons for action there are, for all those subject to the statutory laws they thereby make? And if, as seems obvious, those facts and social facts cannot alone thereby create, modify, or re-shape the application of what genuine reasons for action there are, then what else must additionally be the case for the social facts which constitute laws as valid to generate genuine reasons for action? ${ }^{19}$

Moreover, as all too common experience demonstrates, human social institutions, and their constituent rules and practices, can produce legally valid laws which are morally reproachable or indeed even morally abhorrent. ${ }^{20}$ This being so, then clearly in some cases legal norms do not and should not be taken as providing genuine reasons for action at all. If, then, legal norms do not necessarily or purely in virtue of being legal norms provide (genuine, moral) reasons for action, and if the paradigm case and central hallmark of normativity is that norms $d o$ provide reasons for action, then in what sense exactly, if at all, are legal norms normative? Is the "ought" in "legally, $X$ ought to $\phi$ " a different kind or sense of ought, or an ought with a different meaning, as compared with the oughts of "fullblooded" normativity? How could that be possible? What different kind or sense or meaning of ought could be at work in the legal case? Alternatively, if we reject this idea of a different kind of ought or a different meaning of ought in the legal case, then how can we explain legal normative statements as having the same sense and the same meaning as full-blooded or moral normative statements, when

\footnotetext{
${ }^{19}$ Works in legal and political philosophy addressing exactly such questions, and their relations with questions concerning the normativity of the law, are voluminous, but to mention just a tiny selection here, see e.g. Finnis 2011, chaps. IX-XII; Finnis 2012; Raz 2009, chaps. 1, 2, 12, 13; Raz 1986; Raz 1994 and Raz 1994b, both in Raz 1994a; Green 1988; Gans 1992, Higgins 2004.

${ }^{20}$ See, for instance, the many racially discriminatory statutes produced by the South African apartheid system between 1948 and 1991 at: <http://scnc. ukzn.ac.za/doc/HIST/Apartheid\%20Legislation \%20in\%20South\%20Africa.htm> [retrieved: 07/09/2017].
} 
we know that sometimes - perhaps often- legal norms go morally astray or worse, such that they do not in reality carry the full-blooded normative force which "ought" paradigmatically denotes, and are rightly not taken as having such force by many of those subject to them? In what sense, if any, is a norm lacking in full-blooded normative force really a norm? ${ }^{21}$

These questions lead us to consider others which find much resonance in many commonplace situations in legal and political life. Can an agent act as a judge, or a lawyer, or a civil servant, or a law teacher whilst not being committed to the full-blooded normativity of the legal norms which he/she uses in giving judgement/ advising clients/ writing, executing and applying the law/ understanding and analysing law for the benefit of his/her students? Can an agent act in all or any of those roles whilst being fundamentally morally opposed to the legal norms in question, and/or fundamentally morally opposed to the very notion of legal regulation? We all know of, or perhaps ourselves are, examples of persons who advise on, administer, and apply legal rules whilst being personally morally opposed to some or even most of the norms in question. Indeed some governmental practices, such as having an independent and impartial civil service (as is the case in the UK) whose personnel do not change with a change in government policy or indeed a change in government, seem to presuppose and hold there to be value in legal norms being administered by agents who, at least in some instances for some of the time, do not regard the norms in question as creating genuine reasons for action. ${ }^{22}$

Still more puzzles follow hot on the heels of the issues raised above, puzzles which take us squarely into the realm of law's value and justification conditions: when legal norms $d o$ carry the full-blooded normative force which their "ought" paradigmatically denotes, in virtue of what do they succeed in so doing? Is it merely a matter of legal norms being full-bloodedly normative and generating genuine reasons for action when and to the extent that they adequately "mirror" or perhaps render more determinate, that which moral norms already require? Or do certain aspects of law's institutional, social and systemic character themselves contribute to its potential moral

${ }^{21}$ These questions are discussed extensively in the following works in legal philosophy: Raz 1999, passim but especially chap. 5; Raz 2009, chaps. 7, 8 and 16; Hart 1982, chaps. 6 and 10; Raz 1984.

${ }^{22}$ For discussion, see e.g. Raz 2009, chaps. 7, 8, 16; Hart 2012, chaps. V, VI and IX; Toh 2007; Gardner 2007. 
value and its capacity to add to, alter, and re-shape our reasons for action? ${ }^{23}$

As the footnotes accompanying this section indicate, much important work in contemporary legal philosophy has addressed exactly these issues, and has frequently done so by examining whether and, if so, under what conditions, law has legitimate moral authority and whether and, if so, under what conditions, law creates moral obligations to obey it. For present purposes, it is particularly important to note that such questions require us to understand and explain both the social and institutional character of law, including what Enoch refers to as the "formal normativity" of legal norms, and the relations between these social and institutional features of law and law's ability to generate genuine reasons for action, and to successfully perform valuable functions. This being so, much important work in general jurisprudence focusses precisely on explaining the links between law's social and institutional features -including its "formal normativity" - on the one hand; and its capacity to generate genuine reasons for action, and to instantiate moral value, on the other.

The work of legal theorists such as John Finnis and Joseph Raz strongly exemplifies this. Finnis and Raz devote much of their work in legal philosophy to tackling puzzles surrounding what might be referred to as "the dualities of law". For Raz, a successful theory of law must: "do justice to the multiple dualities of the law" (Raz 2009a, p. 1). Finnis contends that his re-working of natural law theory accepts and adequately explains "that law can be considered and spoken of both as a sheer social fact of power and practice, and as a set of reasons for action that can be and often are sound as reasons and therefore normative for reasonable people addressed by them" (Finnis 2007, Introduction, emphases in original). For both Finnis and Raz, aspects of law's posited character, and of its social and institutional features including those social facts by virtue of which law is created, are precisely what enable law to perform morally valuable functions such as reasonably resolving co-ordination problems for the common good of a community, or providing a structure of authority such that difficult moral problems which could not be solved without the law, can be solved with it. ${ }^{24}$ Indeed, it may be that Enoch's failure to appreciate the inherent links between these different facets of law, and the way in which tackling issues and puzzles regarding

${ }^{23}$ For discussion, see Finnis 2003, Finnis 2007, Raz 1994a.

${ }^{24}$ See Finnis 2011, passim; Finnis 2007; Raz 2003 
one such facet inevitably and wholeheartedly embroils us in examining other facets of law, and the relations between them, is responsible to a significant extent for his view that general jurisprudence is not interesting. I consider this point further in section 4 below.

To conclude the present section: the many and various legal philosophical inquiries canvassed above are inquiries which relate to, stem from, and are engendered by what Enoch refers to as law's "formal normativity". Moreover, as the works in legal philosophy cited in the footnotes to this section demonstrate, this rich and varied buffet of intriguing questions has been and still is being extensively and determinedly wrestled with by legal philosophers in the course of their inquiries into the nature of law. All of this seems to indicate that general jurisprudence only appears to be uninteresting when a peculiarly narrow, idiosyncratic, and ultimately misleading view is taken of which issues it addresses, and the way in which it addresses them.

\section{Complementarity and Continuity in Jurisprudential Inquiry}

What can have led Enoch to adopt such a narrow view of the questions generated by "formal normativity", a view which seems to strive to hermetically seal that issue from a web of interconnected further puzzles about the nature of law? In my view, it stems from a tendency on Enoch's part throughout "Is General Jurisprudence Interesting?" to view various questions in legal philosophy as far more disconnected from one another than they actually are, and to significantly overlook the character and richness of the relations between them. ${ }^{25}$

This tendency is evident in Enoch's discussion of the relative uninterestingness of law's "formal normativity", and it also permeates more generally his discussion of which questions are, and are not, philosophically interesting for legal philosophers to pursue. As regards the former, it is manifest in Enoch"s belief in "Is General Jurisprudence Interesting?", that he can separate off from his discussion of law's normativity, and leave unexplored: puzzles concerning

\footnotetext{
${ }^{25}$ This tendency is rendered the more peculiar by the fact that, in some of his other writings, Enoch is prepared at least to discuss in an exploratory way the possible connections between what he refers to in "Is General Jurisprudence Interesting?" as formal normativity, and a range of further questions concerning law's ability to trigger and otherwise bear upon our genuine, full-bloodedly normative reasons for action: see Enoch 2011. As has been stated throughout the present discussion, my focus here is on Enoch's views as expounded in "Is General Jurisprudence Interesting?" (Enoch 2015).
} 
the character of internal legal statements, especially internal legal statements made by legal officials (Enoch 2015, pp. 14-15); questions regarding whether and when law is normatively relevant and can make a normative difference in our practical reasoning processes (Enoch 2015, pp. 15-16); and issues relating to law's claim to possess legitimate moral authority, and hence to what would be required for it to make good on that claim (Enoch 2015, pp. 17-18). Enoch's approach in this regard also reveals itself powerfully in his unexplained and unelaborated upon claim that issues which he believes are interesting — such as law's power, its ability to affect our lives in deep ways, its ability to structure and alter our practical reasoning processes, and its relations with other social practices whose norms it claims to pre-empt - are simply unrelated to, and hence have nothing significant to gain from or lend to, inquiries concerning the character and operation of law's formal normativity (Enoch 2015, pp. 21-22).

Looking beyond Enoch's views on the philosophical sterility of inquiries concerning law's formal normativity, his tendency to sever those questions he regards as interesting from those he regards as falling within "general jurisprudence" is also apparent in other claims he makes. For instance, without offering argument to support his view, Enoch contends at the article's close that questions concerning law's relations with politics, law's centrality and importance to our polities and to our political processes, the normative constraints incumbent on law, and those values and standards it is rightly subject to: (i) are not presently investigated within general jurisprudence, and (ii) are not really questions about the nature of law $(2015$, p. 31). General jurisprudence, counsels Enoch, thus needs to change course, address those more interesting questions just referred to, and become "part of moral and political philosophy" (2015, p. 31).

The problem with this view, however, in addition to its being asserted without substantiating argument, is that it is inaccurate and misleading. As has been discussed in section 3 above, and as the references in that section to many important works in contemporary legal philosophy indicate, Enoch's interesting questions concerning law's relations with politics, law's centrality and importance to our polities and to our political processes, the normative constraints incumbent on law, and those values it ought to serve, are being addressed, and have a substantial history of being addressed, by legal philosophers working in general jurisprudence. Moreover, many of the works referenced in my discussion in section 3 are works in both legal philosophy and political philosophy, and some of them examine the connections, complementarities, and continuities which 
pertain between legal philosophy and political philosophy. ${ }^{26}$ Finally, it is not at all clear why Enoch regards his interesting questions as "not exactly questions about the nature of law" (2015, p. 31), especially given the extent to which many of them are addressed by legal philosophers in the course of what those theorists regard as inquiries into law's nature. ${ }^{27}$

\section{A Way Forward for the Interested: Elucidating Law by Means of Indirectly Evaluative Legal Philosophy}

In light of the foregoing discussion, a fresh start seems warranted. What approach should we take to general jurisprudence, in order to highlight the philosophical interest of the questions it addresses, and to reveal their myriad, inter-connected, and never-ending character? As jurisprudential food for thought, and to conclude the present discussion, I offer readers, in outline form, my vision of the enterprise of legal philosophy, and the fascinating questions it addresses.

My particular approach to jurisprudential inquiry, which I have referred to elsewhere as "Indirectly Evaluative Legal Philosophy" (hereinafter, "IELP"), ${ }^{28}$ aims to:

- identify and explain significant, important, and illuminating aspects of the nature of law, and consider what it is for law to have a nature, and how truths about its nature are to be ascertained;

- understand and be sensitive to the ways in which the questions of legal philosophy arise in and change over time;

- adequately account for, and explain the relevance of, the selfunderstandings - in terms of the concept of law and related concepts - of those who are subject to, create, and administer the law;

- adopt an approach which resists premature and/or immoderate veneration of law, by proceeding from what we might call an "attitude of due wariness" regarding law, and by postponing, and, in a certain sense, limiting, the role of moral evaluation in our theories of law, until certain questions have been addressed;

${ }^{26}$ See especially those works referenced in note 19 above.

${ }^{27}$ This is the case as regards a variety of questions addressed in those works referred to in notes $18-19$, and notes 22 to 24 above.

${ }^{28}$ See Dickson 2015 for further discussion of the approach which I outline. I draw upon aspects of this article in the remainder of this section. 
- facilitate and engender moral and other evaluation, criticism and reform of the law, tasks which are a vital part of legal philosophy.

I will elaborate a little on each of these in turn.

TENET \#1: IELP seeks to identify and explain significant, important, and illuminating aspects of the nature of law, and consider what it is for law to have a nature, and how truths about its nature are to be ascertained.

This tenet of IELP firmly indicates my belief in the possibility of, and value of engaging in, general jurisprudence, because, in speaking of seeking to understand the nature of law, a distinction is embraced, i.e. the distinction between:

(i) inquiries into the nature of law, which seek to identify and explain what is essential, or necessary, to something being law, and

(ii) inquiries focusing on what is contingent about law, ie on those features which law sometimes exhibits in certain social, cultural, economic, etc, circumstances, but which are not part of its nature.

Some legal philosophers embrace this distinction, and position their work, or certain parts of their work, on one, ${ }^{29}$ or the other, ${ }^{30}$ side of it. Others, however, doubt that the distinction demarcates two viable enterprises, contending that it is implausible, and perhaps impossible, to conceive sensibly of law - a man-made artefact, emerging from social and institutional facts and processes - as having a nature, or having essential properties, which theories of law might attempt to identify and explain. ${ }^{31}$

My own view is that each arm of the distinction - inquiries into the nature of law, and inquiries into law's contingent propertiesindicates a possible, and valuable, theoretical endeavour as regards improving our understanding of law. Indirectly Evaluative Legal Philosophy, with its focus on identifying and explaining the nature of law, is hence just one type of inquiry within a pluralistic disciplinary

${ }^{29}$ Theorists who conceive their work, or parts of their work, as concerning the nature of law, include Raz 2009b, Stavropoulos 2014, Shapiro 2011.

${ }^{30}$ Theorists who regard aspects of their work as concerning law's contingent properties include Giudice 2011, and Cotterrell 2014.

${ }^{31}$ See e.g. Schauer 2012, Tamanaha 2011. 
scene. Several fascinating puzzles then arise when we begin to consider what it means to identify and explain the nature of law. Does law have a nature, and, if so, in what sense? What is the relationship between the nature of law and the concept of law through which we attempt to understand it? Is law an artefact concept, and, if so, does the character of artefact concepts preclude their having a nature, and having essential properties? How should we go about ascertaining truths about the nature of law, and/or the concept of law?

IELP's strong emphasis on identifying and explaining law's significant and important features, and its claim that it is necessary to make indirectly evaluative judgements in order to do so, are also key to the character of this methodological stance. ${ }^{32}$ IELP does not attempt some value-free "flat" description of law, in which the theorist casts a passive and invariantly focused eye over the terrain of law and merely describes — or perhaps "records" captures it better- all that $\mathrm{s} /$ he sees. IELP seeks to elucidate law: to illuminate particular aspects of it; to identify and explain law's important and significant features, and their impact upon the lives of those within law's purview; and to light the way for its moral evaluation, criticism, and reform.

TENET \#2: IELP seeks to understand and be sensitive to the ways in which the questions of legal philosophy arise in and change over time.

It is sometimes tempting to ask: if legal philosophers have been addressing the same questions for hundreds or indeed thousands of years, then shouldn't some conclusive and widely accepted knowledge have been attained by now, at least as regards some of those questions? And if this has not been the case, doesn't this indicate a problem with the questions we keep asking, and the ways in which we attempt to address them?

This, however, is to misunderstand the character, aims, and criteria of success of legal philosophy. IELP seeks to emphasize and explore the sense in which the questions of legal philosophy have not remained the same throughout the history of the discipline, but rather arise in and change over time, in response to changing interests and concerns. One example of this is the fluctuating jurisprudential interest in the theory of legal systems. The late 1960s and early to mid-1970s witnessed a flurry of legal philosophical interest in questions surrounding the identity of legal systems (such as which criteria

${ }^{32}$ See, further, Dickson 2015, Dickson 2001, Dickson 2004. 
determine when norms belong to one and the same legal system, how we should understand the limits of legal systems and their relations with norms from outside the system in question) and their continuity through time (such as how do we know when an existing legal system has been replaced by a new one, when one legal system has split into two, or two such systems joined into one?). A focus on such questions was prompted in part by puzzles generated by the journey to political independence taken by certain former colonial nations. ${ }^{33}$ Once these developments largely ran their course, interest in the theory of legal systems waned dramatically, and, arguably, without many of the relevant issues having been understood satisfactorily. However, in recent times, the proliferation and increased importance of forms of non-state and non-single-legal-system legality — such as is found in the supranational legal arrangements of the contemporary European Union, and in other areas of international and transnational lawhas rejuvenated scholarship on the character, puzzles, and applicability of the concept of a legal system, and this topic has become avidly debated once again. ${ }^{34}$

The fluidity, change, innovation, and diversification as regards the foci of jurisprudential inquiry deserves further study, and should be viewed as indicative of enduring disciplinary vibrancy.

TENET \#3: IELP seeks to adequately account for, and explain the relevance of, the self-understandings - in terms of the concept of law and related concepts - of those who are subject to, create, and administer the law.

When legal philosophers come to try to identify and elucidate aspects of law's nature, they are attempting to explain that which is picked out by a concept which is already used by users of that concept to understand themselves and their lives in terms of law. Those in societies governed by law think and speak of issues such as who gets to make law, what input others should have as regards the law-making process, and whether the law so made is just, fair, and offers appropriate solutions to difficult social problems. They consider and contrast what law requires, and what morality, family obligations, or their religion requires, and are familiar with dilemmas created by different normative standards simultaneously applicable to them in certain situations.

${ }^{33}$ See e.g. Honoré 1967, Finnis 1973, Eekelaar 1973.

${ }^{34}$ See, for instance, Giudice and Culver 2010, von Daniels 2010, Giudice and Culver 2012, in Dickson and Eleftheriadis 2012. 
Consequently, legal philosophy is constrained in the character of the explanations it gives: it must seek to elucidate law in a way which does adequate justice to how it is already understood, and is understood to feature in, the lives of those who create, administer, and are subject to it. But what exactly does this constraint amount to? Being appropriately attuned and sensitive to the existing selfunderstandings of those living under law nonetheless leaves much work for the theorist to do, including making discerning and illuminating value judgements of various kinds, in order to separate the central from the peripheral, the deeply held from the superficial, and in order to hew from the "raw material" of those existing selfunderstandings, a cogent account of the character of law. ${ }^{35}$ But many interesting questions remain. How far can and should legal theorists go in systematizing, rendering more coherent, and extrapolating from existing self-understandings? What are the proper limits of conceptual revisionism in this regard?

TENET \#4: IELP aims to avoid premature and/or immoderate veneration of law, by proceeding from what we might call an "attitude of due wariness" regarding law, and by postponing, and, in a certain sense, limiting, the role of moral evaluation until certain questions have been addressed.

This tenet has its roots going all the way back to the work of Jeremy Bentham. Bentham sought to strip away the cloak of moral veneration which he believed Blackstone and others had draped around law, in order that we might see clearly and in the cold light of day, its character, and what exactly it was asking of us. Only then, with such a cool-headed and un-romanticized understanding of law in mind, would we be able effectively to evaluate and reform it, with moral and social progress as our lodestar. ${ }^{36}$

IELP, too, is committed to building a cool-headed account of law as it is, prior to, and relatively independent of, morally evaluating, criticizing and reforming it. IELP is deeply concerned with the moral and other evaluation, criticism and reform of law, but it advocates approaching those goals via a somewhat indirect route. Two key aspects of law's character and operation prompt such an approach, and justify legal philosophers' adopting an "attitude of due wariness" towards it.

\footnotetext{
${ }^{35}$ See Dickson 2011 for further discussion of this point.

${ }^{36}$ See Hart 1982a in Hart 1982, and those works by Bentham referred to by Hart in this illuminating essay.
} 
The first concerns the many rhetorical, symbolic, linguistic, and other "tricks" that law has up its sleeve, which may serve to persuade us prematurely of its moral value and obligatoriness. Law presents itself to us bedecked in archaic and baroque language, terminology, phraseology, and forms of address largely impenetrable to those not educated in its ways. Its most public face is shown in grandiose buildings, in distinctive and often hierarchical court etiquette and procedure, and its associated nomenclature - "Ministry of Justice", "Royal Courts of Justice" - has its institutions appearing by their very name to be holding themselves out as not merely aspiring to, but delivering, justice. Such features of law can generate an obscurantist fog around law, creating an air of mystery and majesty such as prematurely to convince us that law ought to be venerated and obeyed.

Secondly, where law operates, the stakes are high. Law claims comprehensiveness regarding those areas of human life that it may regulate. It regulates matters of considerable moral and other importance to us; as individuals, and in terms of the societies in which we live. But human history stands obvious and powerful witness to the fact that human beings, and the social institutions they create and administer, have given (and continue to give) legal shape to a range of morally repugnant social arrangements and forms of social organization. ${ }^{37}$ Moreover, when law and its officials get things wrong and fall into moral and other error, the consequences for us and for our societies are far more serious than when an individual goes thus astray. Law operates on a mass scale, applying itself compulsorily and often coercively to whole population sets at a time. Errors perpetuated by a social institution of this character have the capacity to be wide-ranging, far-reaching and to have deep and sometimes catastrophic effects on the life-chances of those living under it. These aspects of law's character justify approaching it, as IELP does, with an attitude of due wariness.

An example of how this attitude might play out in practice in an account of law can be found by returning to some of the issues discussed in section 3 above. In that section, I argued that questions concerning what Enoch refers to as law's "formal normativity" gain some of their considerable philosophical interest from the way in which they raise, and are necessarily involved in addressing, other questions concerning, for example, law's ability to generate genuine reasons for action. If we want to address the puzzle of how, if at

${ }^{37}$ See note 20 above. 
all, social facts can generate reasons for action, then we first need to know what those social facts are, how they arise, and what claims they make of us. Approaching law with an attitude of due wariness ensures we will give appropriate analytical focus to understanding how, and what, law claims of us, while not being too quick to assume that the social facts of which law is comprised can generate genuine reasons for action at the outset of our inquiry. By first of all analyzing the origins, character, and claims of law's "formal normativity" we will then be in a better position to see whether, and, if so, under what conditions, that "formal normativity" can bring in its wake "full-blooded" normativity. Far from lacking philosophical interest, questions regarding law's formal normativity, can, when approached via an appropriate methodological attitude, be a powerful analytical tool allowing us to open up and explore further questions regarding law's value, without prejudging them, and without prematurely, or inappropriately, venerating law.

TENET \#5: IELP seeks to facilitate and engender moral and other evaluation, criticism and reform of the law, tasks which are a vital part of legal philosophy.

IELP is acutely concerned with those moral and other evaluative standards to which law should be held, and with the place of law in our practical reasoning processes and well-being. Indirectly Evaluative Legal Philosophy, however, differs from some other approaches in contending that such matters must be approached and answered in stages, and that a significant part of the work of identifying and understanding important features of law relevant to law's moral evaluation, can and should be done while postponing and limiting the role of moral evaluation in our theories until certain questions have been addressed, and a certain stage in the inquiry reached.

On this view, the first "stage" of our inquiries into the character of law ought not to be morally evaluative, let alone morally commendatory or justificatory in its approach. Instead, this "first stage" of legal philosophical inquiry involves identifying and explaining law's important and significant features. Many of those features so identified and explained will be highly relevant to law's eventual moral evaluation and criticism, and many of them will be important and significant precisely because they are relevant to law's moral evaluation and criticism. For example, law's claim to possess moral authority, and the normative consequences of that claim, are important and significant features of law. They are important and significant because they bear upon what matters to us regarding the effects law can have on our 
lives, and because they are acutely relevant to the judgements we must make concerning what attitude we ought to adopt towards law and whether we ought morally to obey it.

Once again, these points find echoes in the discussion of Enoch's work earlier in this paper. In section 4 , I was at pains to emphasize that questions such as those relating to law's "formal normativity" and questions relating to its moral purpose and value, and the conditions under which it generates genuine reasons for action, are significantly linked, hence giving the lie to aspects of Enoch's apparently isolationist view of the proper domain and questions of general jurisprudence. This complementarity and continuity between sets of questions addressed by legal philosophy must be adequately appreciated in order better to understand the discipline, and its distinctive philosophical interest. As tenet \#5 above indicates, IELP very much seeks to emphasize these points, and also to supplement them by explaining the way in which each set of questions is better and more thoroughly investigated by addressing them in a certain order, and without prematurely judging issues such as law's moral value, and the circumstances, if any, under which it generates genuine reasons for action.

According to IELP, then, there is no doubt that we must investigate law's claims and abilities as regarding generating genuine reasons for action, its possible moral point or purpose, its moral legitimacy and authority. However, at the outset of our investigations, our attitude should be: moral evaluation and criticism of law, but not yet. Why not yet? To a significant extent, because of those points discussed in tenet \#4 above: a fear of prematurely venerating law; a wariness of developing an unquestioning attitude towards it and being too-ready to comply with it; and an acute awareness of the potential morally and socially disastrous effects of such attitudes.

IELP thus rejects any notion that it is isolationist in character, and seeks to divorce legal philosophy from the rest of political, social and moral philosophy. Some theorists, Enoch amongst them, write as if it is up for grabs whether legal philosophy is in some sense part of, continuous with, and fruitfully related to, political, social, and moral philosophy. The reality is that none of this is in doubt. The issue is not whether legal philosophy is part of and continuous with inquiries in political, social, and/or moral philosophy. The issues are: what is the exact character of the relations between these enterprises, and in what precise sense is legal philosophy part of, continuous with, and tied to them? 
All the questions and puzzles outlined in this section, and those discussed more generally in this article as a whole, take their rightful place in the province of general jurisprudence, properly understood. And they all seem pretty interesting to me..$^{38,39}$

\section{REFERENCES}

Cotterrell, R., 2014, "Why Jurisprudence Is Not Legal Philosophy", Jurisprudence, vol. 5, pp. 41-55.

DeLillo, D., 1985, White Noise, Viking, New York.

Del Mar, M. (ed.), 2011, New Waves in Philosophy of Law, Palgrave Macmillan, London.

Dickson, J., 2015, "Ours Is a Broad Church: Indirectly Evaluative Legal Philosophy as a Facet of Jurisprudential Inquiry", Jurisprudence, vol. 6, pp. 207-230.

— 2012, "Towards a Theory of European Union Legal Systems", in Dickson and Eleftheriadis 2012, pp. 25-53.

—_, 2012a, "Legal Positivism: Contemporary Debates", in Marmor 2012, pp. $48-64$.

— 2011, “On Naturalizing Jurisprudence: Some Comments on Brian Leiter's View of What Jurisprudence Should Become", Law and Philosophy, vol. 30, pp. 477-497.

- 2004, "Methodology in Jurisprudence: A Critical Survey", Legal Theory, vol. 10, pp. 117-156.

—- 2001, Evaluation and Legal Theory, Hart Publishing, Oxford.

phy, Oxford University Press, Oxford.

Dickson, J., and P. Eleftheriadis (eds.), 2012, Philosophical Foundations of European Union Law, Oxford University Press, Oxford.

Eekelaar, J.M., 1973, "Principles of Revolutionary Legality", in Simpson 1973, pp. 22-43.

Enoch, D., 2015, "Is General Jurisprudence Interesting?", available at SSNR: <https://papers.ssrn.com/sol3/papers.cfm?abstract_id=2601537> or <http://dx.doi.org/10.2139/ssrn.2601537>; and forthcoming in D. Plunkett, S. Shapiro, and K. Toh (eds.), Dimensions of Normativity:

${ }^{38}$ Giving a fuller account of "Indirectly Evaluative Legal Philosophy" is a central task of my current "book-in-progress", provisional title, Elucidating Law: The Philosophy of Legal Philosophy (under contract with Oxford University Press), Dickson, forthcoming.

${ }^{39}$ I would like to thank Pau Luque for his invaluable guidance and for his interest in my work, and two anonymous reviewers whose helpful comments have improved this article. This article is dedicated to the memory of my mum, Janet Dickson, who embodied and encouraged all that true education ought to bring us. 
New Essays on Metaethics and Jurisprudence, Oxford University Press, New York.

Enoch, D., 2011, "Reason-Giving and the Law", in L. Green, and B. Leiter (eds.), Oxford Studies in Philosophy of Law: Volume 1, Oxford University Press, Oxford, pp. 1-38.

Finnis, J., 2012, "What Is the Philosophy of Law?", Rivista di Filosofia del Diritto, vol. 1, pp. 67-78.

— , 2011, Natural Law and Natural Rights, 2nd ed., Oxford University Press, Oxford.

- 2007, "Natural Law Theories", The Stanford Enyclopedia of Philosophy (Winter 2016 edition), Edward N. Zalta (ed.): <http:// plato.stanford.edu/entries/natural-law-theories/> [retrieved: 07/09/2017].

— 2003, "Law and What I Truly Should Decide", American Journal of Jurisprudence, vol. 48, pp. 107-129.

— 1973, "Revolutions and Continuity of Law", in Simpson 1973, pp. 44-76.

Gans, C., 1992, Philosophical Anarchism and Political Disobedience, Cambridge University Press, Cambridge.

Gardner, J., 2012, Law as a Leap of Faith, Oxford University Press, Oxford.

— , 2007, "Nearly Natural Law", American Journal of Jurisprudence, vol. 52, no. 1, article 1; available at: < https://scholarship.law.nd.edu/ajj/ vol52/issl/1 $>$ [retrieved: 07/09/2017].

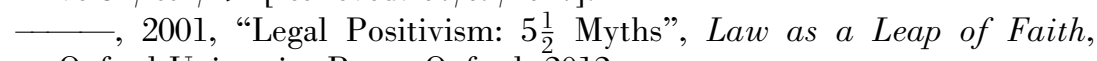
Oxford University Press, Oxford, 2012.

Giudice, M., 2011, "Analytical Jurisprudence and Contingency", in M. Del Mar (ed.), New Waves in Philosophy of Law, Palgrave Macmillan, London, 2011, pp. 58-76.

Giudice, M., and K. Culver, 2012, "Not a System but an Order: An InterInstitutional View of European Union Law", in Dickson and Eleftheriadis 2012, pp. 54-76. ford.

Green, L., 2003, "Legal Positivism", in The Stanford Encyclopaedia of Philosophy, (Spring 2018 edition), Edward N. Zalta (ed.), forthcoming at: <http://plato.stanford.edu/entries/legal-positivism/> [retrieved: $07 / 09 / 2017]$.

- 1988, The Authority of the State, Oxford University Press, Oxford.

Hart, H.L.A., 2012, The Concept of Law, 3rd ed., with a Postscript edited by P.A. Bulloch and J. Raz; introd. and notes L. Green, Clarendon Press, Oxford University Press, Oxford.

—, 1983, "Definition and Theory in Jurisprudence", Essays in Jurisprudence and Philosophy, Clarendon Press, Oxford, pp. 21-48.

$\longrightarrow$, 1982, Essays on Bentham, Oxford University Press, Oxford. 
Hart, H.L.A., 1982a, "The Demystification of the Law", Essays on Bentham, Oxford University Press, Oxford.

Honoré, A.M., 1967, "Reflections on Revolutions", Irish Jurist, vol. 2, no. 2 , pp. 268-287.

Higgins, R., 2004, The Moral Limits of Law: Obedience, Respect, and Legitimacy, Oxford University Press, Oxford.

Leiter, B., 1998, "Realism, Hard Positivism and Conceptual Analysis", Legal Theory, vol. 4, pp. 533-547.

Lurie, A., 1984, Foreign Affairs, Random House, New York.

MacCormick, N., 2007, Institutions of Law: an Essay in Legal Theory, Oxford University Press, Oxford.

Marmor, A. (ed.), 2012, Routledge Companion to the Philosophy of Law, Routledge, London/New York.

Raz, J., 2009, Between Authority and Interpretation, Oxford University Press, Oxford.

—_, 2009a, "Can There Be a Theory of Law?", in Raz 2009, pp. 17-46.

-, $2009 \mathrm{~b}$, The Authority of Law, 2nd ed., Oxford University Press, Oxford.

—_ 2007, "The Argument from Injustice, or How Not to Reply to Legal Positivism", in G. Pavlakos (ed.), Law, Rights and Discourse: The Legal Philosophy of Robert Alexy, Hart Publishing, Oxford, pp. 17-35.

—_, 2004, "Incorporation by Law", Legal Theory, vol. 10, pp. 1-17.

- 2003, "About Morality and the Nature of Law", American Journal of Jurisprudence vol. 48, pp. 1-16.

- 1999 , Practical Reason and Norms, 2nd ed., Oxford University Press, Oxford.

—_, 1994, "Authority, Law and Morality", in Raz 1994a, pp. 210-237.

—_ 1994a, Ethics in the Public Domain, Clarendon Press, Oxford.

- $1994 b$, "The Obligation to Obey: Revision and Tradition" in Raz 1994a, pp. 341-354.

— 1 , 1986, The Morality of Freedom, Clarendon Press, Oxford.

- 1985, "Authority and Justification", Philosophy and Public Affairs, vol. 14, pp. 3-29.

Legal Studies, vol. 4, pp. 123-131.

Russo, R., 1997, Straight Man, Random House, New York.

Schauer, F., 2012, "On the Nature of the Nature of Law", Archiv für Rechtsund Sozialphilosophie, vol. 98, pp. 457-467.

Shapiro, S., 2011, Legality, Harvard University Press, Cambridge, Mass.

Shapiro, S., and D. Plunkett, 2017, "Law, Morality and Everything Else"; available at: <https://papers.ssrn.com/sol3/papers.cfm?abstract_id= 2964089> [retrieved: 07/09/2010].

Simpson, A.W.B. (ed.), 1973, Oxford Essays in Jurisprudence, Second Series, Oxford University Press, Oxford. 
Stavropoulos, N., 2014, "Legal Interpretivism", Stanford Encyclopedia of Philosophy (Summer 2014 edition), Edward N. Zalta (ed.), available at: <http://plato.stanford.edu/entries/law-interpretivist/> [retrieved: 07/09/2017].

Tamanaha, B., 2011, "What is 'General' Jurisprudence? A Critique of Universalistic Claims by Philosophical Concepts of Law", Transnational Legal Theory, vol. 2, pp. 287-308.

Toh, K., 2007, "Raz on Detachment, Acceptance and Describability", Oxford Journal of Legal Studies, vol. 27, pp. 403-427.

Von Daniels, D., 2010, The Concept of Law From a Transnational Perspective, Ashgate Press, Farnham.

Waluchow, W., 2000, "Authority and the Practical Difference Thesis: A Defense of Inclusive Legal Positivism", Legal Theory, vol. 6, pp. 45-81. - - 1994, Inclusive Legal Positivism, Oxford University Press, Oxford.

Received: February 27, 2017; revised: July 24, 2017; accepted: September 6, 2017. 